This item was submitted to Loughborough's Institutional Repository (https://dspace.lboro.ac.uk/) by the author and is made available under the following Creative Commons Licence conditions.

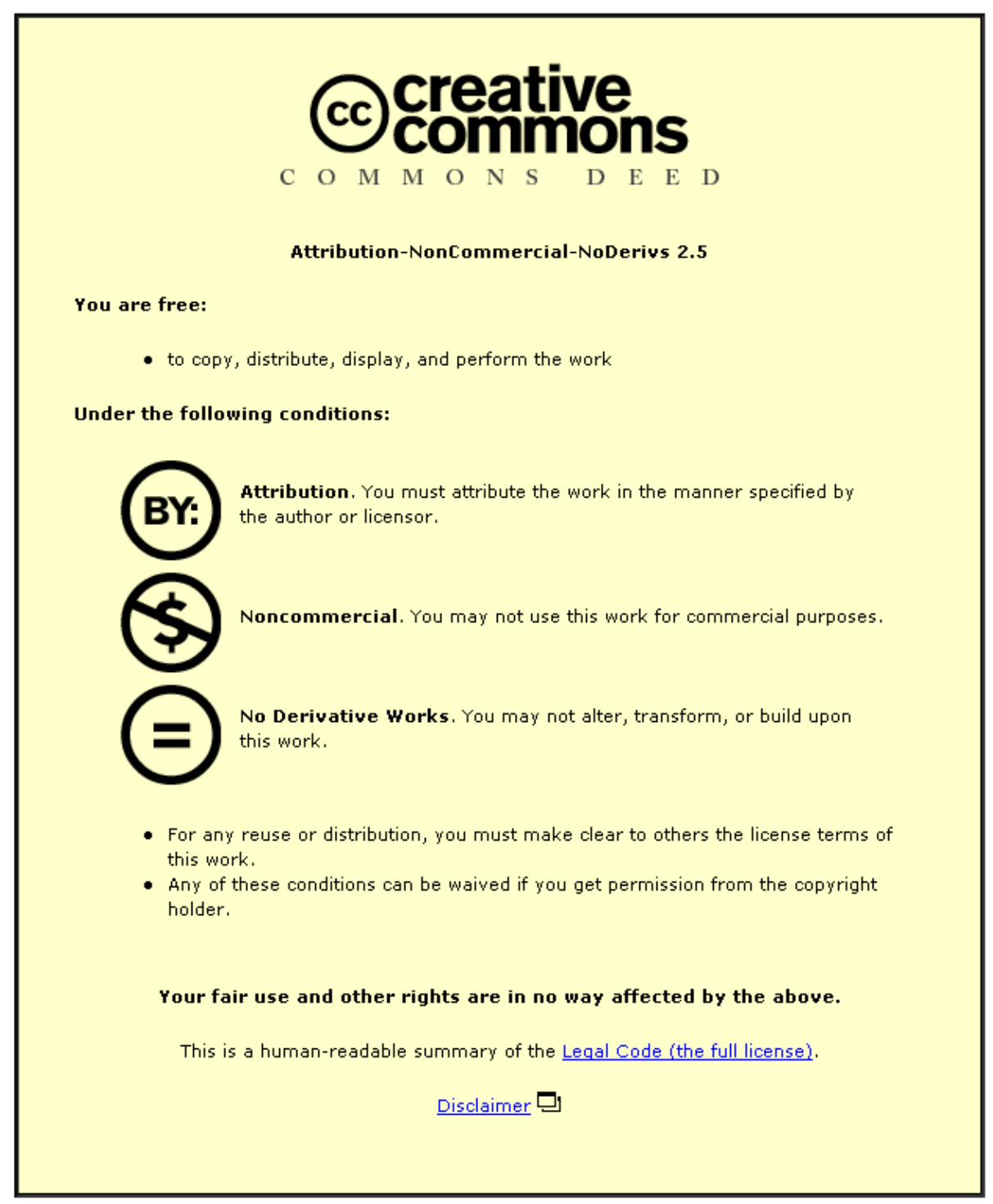

For the full text of this licence, please go to: http://creativecommons.org/licenses/by-nc-nd/2.5/ 


\title{
Pond biodiversity and habitat loss in the UK
}

\author{
Wood, P.J. ${ }^{1}$, Greenwood, M.T. ${ }^{1}$ and Agnew M.D. ${ }^{2}$
}

1. Department of Geography, Loughborough University, Loughborough, Leicestershire, LE11 3TU, UK.

Email:-p.j.wood@lboro.ac.uk

m.t.greenwood@lboro.ac.uk

2. School of Environmental Sciences, University of East Anglia, Norwich, NR4 7TJ, UK.

Email:-m.agnew@uea.ac.uk

\section{Author for Correspondence}

Dr Paul J Wood

Department of Geography

Loughborough University

Loughborough

Leicesterhsire

LE11 3TU

Tel:- 01509223012

Fax:- 01509223930

Email:-p.j.wood@lboro.ac.uk 


\title{
Pond biodiversity and habitat loss in the UK
}

\begin{abstract}
Ponds are common landscape features but have been poorly studied compared to other freshwater habitats in the UK, despite their high frequency of occurrence. In the last century, many ponds have been lost and those that remain face increasing pressure due to agricultural land drainage, pollution and urban development. However, ponds provide important habitats for diverse floral and faunal communities including a number of rare taxa of conservation interest. This paper examines the biodiversity and wider environmental value of ponds with particular reference to the aquatic invertebrate and amphibian communities they support, and the adverse impact of anthropogenic activity on their aquatic habitats.
\end{abstract}

Key Words:- ponds, UK, aquatic invertebrates, biodiversity, conservation, habitat loss. 


\section{Introduction}

The study of riverine catchments has formed a central role in the development of physical geography and particularly geomorphology, hydrology and more recently biogeography (Calow and Petts 1994). In contrast, the study of standing water bodies (lentic ecosystems) has lagged somewhat behind running water systems, although their use in palaeoenvironmental and palaeoecological research is widely acknowledged (e.g., Berglund 1996; Birks et al 2000). Standing (still) water bodies provide an ideal opportunity to examine biogeographical patterns and relationships since the aquatic organisms that occupy them effectively inhabit aquatic islands in a sea of land. The aquatic organisms that inhabit ponds, small water bodies between $1 \mathrm{~m}^{2}$ and 2 ha in area which hold water for all or part of the year (Pond Action 1993; Rouen 2001), face similar pressures to terrestrial organisms on oceanic islands. They provide ideal sites to examine island biogeography theory (Bilton et al 2001), including the effect of geographic distance between sites on the colonisation and dispersal of different taxa, and the impact of habitat isolation on pond populations (Boecklen 1997; Griffiths 1997).

Small standing water bodies (including pools, marl and brick pits, dells, bog pools, kettle holes and lagoons - herein collectively termed ponds) have been poorly studied in the UK despite the high density of occurrence in both rural and urban locations and are of considerable cultural, recreational and biological value. Ponds are a natural element of the landscape, although they have been poorly incorporated into traditional landscape studies compared to riverine (e.g., Gardiner 1997) and other terrestrial ecosystems (e.g., Burger 2000; Miles et al 2001). The principal reasons for this deficiency reflects the fact that the effective pond landscape (pondscape) includes the pond and its immediate catchment, but also the terrestrial matrix of land between ponds. As a result, land management activities 
some distance away from the waterbody may threaten individual ponds or complexes in both rural and urban locations (Boothby 1997). This has considerable importance when considering the dispersal of aquatic organisms (such as aquatic insects and amphibia) from their birth pond and the colonisation of new or adjacent ponds. In the case of amphibians the pondscape matrix also strongly influences foraging activity and the availability of suitable winter hibernation sites (Griffiths 1997).

Ponds account for around $97 \%$ of the total number of standing water bodies in the UK but only $14 \%$ of the total surface area (Bailey-Watts et al 2000). They have been created by a variety of natural processes such as glaciation, land subsidence, river action and tree falls, although in the contemporary landscape anthropogenic activities are widely acknowledged as the dominant force influencing their creation and elimination in temperate latitudes (Rackham 1986). Ponds are naturally more common in areas with impervious geologies where surface waters easily collect in depressions. However, this pattern is not always clear since large numbers of irrigation, livestock and dew-ponds have historically been created in areas underlain by highly porous rock (e.g., chalk and limestone) where natural surface waters are uncommon, to ensure reliable water sources for agriculture (Beebee 1997; Stanton 1995).

Ponds occur in almost all landuse types including mountainous uplands, moorlands, woodlands, grasslands, coastal margins and in all agricultural settings. They have considerable aesthetic value and historically medieval fish ponds were an important source of food (Rees 1997). Ponds have been created for a wide variety of functions including mineral extraction (Andrews and Kinsman 1990), watering livestock, irrigation for agriculture (Gee et al 1997), as ornamental features (Williams et al 1997), and even to 
drive industrial processes (Giles and Goodall 1992). The amenity value of ponds is widely acknowledged and they are commonly incorporated as hazard features on golf courses (Stubbs 1999), and extensively utilised for recreational angling (Williams et al 1998).

The total number of ponds in the UK is not known, although Rackham (1986) estimated that around 800,000 ponds existed in England and Wales in 1880, based on detailed analysis of Ordnance Survey Maps and applying a correction factor for ponds less than 6 $\mathrm{m}$ in diameter that would have not been surveyed. A similar survey for the 1920's estimated that around 340,000 ponds existed although there was considerable spatial variability across England and Wales (Figure 1). The lowest density of ponds occurred in upland areas and the highest in areas of ancient woodland and agricultural land in Norfolk, Suffolk and Cheshire. The Lowland Pond Survey 1996 estimated the number of lowland ponds in Great Britain to be around 228,900 (Williams et al 1998). However, almost all attempts to determine the number of ponds in an area will be an underestimate. Four main sources of error exist:- i) analysis of historical maps only identifies larger ponds that have been surveyed; ii) even the most extensive field survey will not capture all sites and there is a bias towards larger ponds; iii) a large proportion of naturally ephemeral ponds that hold water for a few months or even weeks each year have been overlooked historically; and iv) the total number of ornamental garden ponds in the urban environment has never been estimated.

Ponds are essentially ephemeral, sedimentation and hydroseral succession gradually leading to the terrestrialisation of a pond through loss of open water and a reduction in depth until the basin is largely indistinguishable from the surrounding land. Due to the naturally ephemeral nature of ponds it has been argued that even anthropogenically 
created sites provide habitat for flora and fauna that is indistinguishable from that of a natural pond (Biggs et al 1994).

Most ponds do not have any statutory protection in the UK (Mackay 1997) and little routine scientific monitoring of their biological resources has been undertaken. There is increasing concern that many ponds have been lost due to changes in agricultural practices, land drainage and urban development. This paper considers the ecological value of ponds in terms of the biological diversity they support (biodiversity - the number of species in a particular area or community (Allaby, 2000)) and the threats that ponds and the organisms that inhabit them face, due to habitat loss and management in the UK.

\section{Pond Biodiversity}

Until recently, the ecology of ponds in the UK has been poorly studied. Their relatively small size and high frequency of occurrence led to the widely held belief that they were ecologically unimportant. However, it has now been acknowledged that this common misconception may have inadvertently allowed many ponds to be drained with little or no regard to aquatic habitat loss or biodiversity (Everard et al 1999).

Ponds provide a significant biological resource. Data collected as part of the Lowland Pond Survey 1996 clearly demonstrates that they support a greater number of aquatic macroinvertebrate species (animals without a backbone greater than $0.5 \mathrm{~mm}$ in size), and particularly uncommon species with specific conservation interest, than riverine systems (Table I) (Williams et al 1998). In addition, the wide variety of ponds occurring in the UK comprise an important habitat for around 400 species of aquatic plants and approximately 150 of the 280 wetland invertebrates listed for conservation value in the UK Red Data 
Book (Duigan and Jones 1997). This includes 23 of the 38 fresh and brackish water organisms given specific protection under Schedules 5 and 8 of the Wildlife and Countryside Act, more than any other freshwater habitat (Table II). The significance of ponds as habitats and refugia for 'rare' species is clear although common and ubiquitous organisms are most frequently encountered, even in the most degraded urban and industrial locations (Wood and Barker, 2000).

The following case study illustrates the high conservation value of the beetle (Coleoptera) community within a single brackish water pond and the wider value of this geographically limited resource. Coastal ponds may support populations of freshwater, marine and specialist brackish water organisms (Sherwood et al 2000). Brackish water ponds depend on a regular input of freshwater, largely derived from rainfall or inflowing streams, and groundwater, which dilutes the seawater. However, during the summer months evaporation processes may concentrate marine salts within the pond creating hypersaline conditions, excluding most faunal species. Coastal brackish water ponds are predominantly located close to or above the spring tide high water line and may only receive marine water input in the form of sea-spray. In some locations individual sites may support nationally significant communities and populations of organisms. A number of nationally rare aquatic beetles (Coleoptera) with restricted distributions utilise these uncommon and relatively hostile habitats (Foster 2000, Sage 1996).

Enochrus bicolor (Hydrophilidae) is a nationally notable water beetle in the UK (Foster 2000). Throughout the UK and Ireland, E. bicolor is confined to brackish water and has been recorded in coastal ponds, slow-flowing ditches and the Cheshire meres (Figure 2). A four-year study of a population of E. bicolor from a saltmarsh pond created in 1850 to 
provide access to an oyster processing plant, Brightlingsea, Essex, identified a dynamic community of organisms of national significance (Greenwood and Wood 2003). The salinity of the pond was variable but attained almost twice the salinity of seawater during the summer of 1997. Of the 31 aquatic organisms identified at the Flag Creek site, 11 Red Data Book Coleoptera were recorded, 10 being nationally scarce and 1 being nationally endangered, Paracymus aeneus (Table III).

Examination of historic distribution records indicated that $P$. aeneus is currently confined to two $10 \mathrm{~km}$ grid squares in England, having only ever been recorded from a total of six $10 \mathrm{~km}$ grid squares. $P$. aeneus lives in saline pools above the high-water mark, usually in association with vegetation at the edge of ponds. In the UK this species is classified as endangered and has been given full protection under Schedule 5 of the Wildlife and Countryside Act 1981 (Table II). A Biodiversity Action Plan has been developed for $P$. aeneus with an emphasis on the protection of existing populations from damaging activities and the creation of additional habitats (shallow ponds with marginal vegetation) around the high-water mark (Foster 1999).

Essex provides an important centre for brackish water habitats along a narrow coastal corridor, containing $20 \%$ of the national saltmarsh habitat (Mason et al 1991). A large proportion of this habitat is under threat from rising sea level, pollution, construction of sea defences and land drainage (Barnes 1989). In addition, overall pond loss within the county between 1870 and 1989 was estimated to be $55-69 \%$ based on map and field surveys of selected areas, with around a 20\% loss since 1960 (Heath and Whitehead 1992). 


\section{Habitat Loss}

The destruction of pond habitats has three component, straightforward loss of habitat, increased fragmentation of the remaining habitat, and reduced habitat quality. Fragmentation can be defined as the remaining habitat of fixed total area that is located within increasingly smaller and more isolated discrete fragments (patches) (Hanski 1999). Habitat loss and fragmentation usually occur together and have undoubtedly lead to greater pressure on a number of pond species due to a reduction in dispersal and colonisation opportunities (Godreau et al 1999; Müller 2003).

Attempts to quantify pond loss are difficult since the total number of ponds in the UK is unknown. It is widely acknowledged that natural succession, agricultural land drainage and developments for urban housing, industry or transport infrastructure have significantly reduced the number of ponds over the last 150 years (Boothby and Hull 1997). Regional estimates of loss vary widely from $90 \%$ for parts of London (Langton 1985) to $6 \%$ for urban ponds in Edinburgh (Jeffries and Mills 1990) (Table IV). However, direct comparison between studies is not always possible since many only provide an estimate of pond number, or rates of pond loss, rather than definitive figures. Pond loss appears to have been greater in the last two decades than during any other period (Boothby et al 1995). Data from the Lowland Pond Survey 1996 (Williams et al, 1998) indicate that most ponds lost between 1990 and 1996 were from arable land while there was a net increase on pastural land.

The importance of both perennial and temporary ponds for amphibian populations is widely recognised, since all seven British species utilise ponds for breeding and larval development (Griffiths, 1997). The decline of great crested newt (Triturus cristatus) 
populations is largely due to the destruction or pollution of their habitat. Elimination of even a limited number of great crested newt breeding sites may have far reaching consequences since adult newts have a tendency to migrate towards their traditional breeding sites and individuals are unable to travel more than $900 \mathrm{~m}$ (Oldham and Humphries 2000). To compound the problems of habitat loss, newt larvae require open water and as a result are particularly vulnerable to predation by fish (Buckley 2001).

Many ponds support fish populations that have been artificially stocked with either coarse or salmonid fish. In some instances recreational angling has lead to the protection of individual ponds, particularly in urban locations (Wood et al 2001a); although due to the predatory nature of many fish there is increasing evidence that reduced amphibian and invertebrate biodiversity occurs in angling ponds (Müller et al 2003). However, evidence from other studies indicates that aquatic plant (macrophyte) diversity may be increased by the management activities associated with angling (Linton and Goulder 2000).

Temporary ponds, standing water bodies that experience a recurrent dry phase (Williams et al 2001) are probably at greater threat in the UK than any other small water body. A major reason for this is a lack of public awareness and scientific research. Even within recognised conservation areas, temporary ponds have been ignored when compared to permanent water bodies - lakes, streams and rivers and perennial ponds. However, temporary ponds are some of the most long-lived, with some ephemeral pingos (ancient periglacial ponds) in Britain more than 8,000 years old. Temporary ponds are typically shallow and are more vulnerable to soil drainage in agricultural and urban areas than permanent waterbodies. To compound this problem, their low water volume combined with a small catchment, makes them highly susceptible to pollution (Williams et al 1998). 
The periodic desiccation of habitat within temporary waterbodies means that there is usually relatively little overlap in the species composition compared to that of perennial ponds (Collinson et al 1995). However, temporary ponds frequently have high floral and faunal biodiversity (Nicolet 2001). Some invertebrate taxa have life cycles that enable them to utilise ephmeral aquatic habitats and some adults and eggs may even be able to withstand partial or complete desiccation (Bratton and Fryer 1990, Drake 2001). In addition, the recurrent dry phase allows a number of semi-aquatic, terrestrial and riparian taxa to utilise the pond basin even when it is dry (Lott 2001).

All amphibian species have been impacted by temporary pond habitat loss to varying degrees; although natterjack toad (Bufo calamita) populations have experienced the most significant reductions over the last century (Denton et al, 1997, Oldham and Humphries 2000). The natterjack toad (Bufo calamita) relies on ephemeral ponds in open early sucessional habitats for reproduction. They require unshaded, shallow ponds (less than 10 cm deep) with gently sloping banks for tadpoles and toadlets to develop successfully. Today, temporary freshwater ponds in the coastal dune systems of the west and east coast of England provide the species' only stronghold. Historically, temporary ponds in pastoral fields and on heathland supported viable populations in several parts of the UK. However, land drainage and changes in the management of heathland have eliminated almost all inland populations (Buckley 2001).

\section{Future Prospects}

Ponds support considerable biodiversity reflecting the many different types of pond and habitats they contain. Detailed medium to long-term studies of pond ecology, hydrology 
and water chemistry are required to provide information on natural hydrological variability and population dynamics to facilitate management and ultimately allow modelling of the pond resource under scenarios of environmental change (Bailey-Watts et al 2000). Long-term datasets are widely available for lakes (e.g. Savage 2000) and riverine systems (Speirs et al 2000), and the data has been widely incorporated into hydroclimatological and eco-hydrological models (Bradley and Ormerod 2001, Wood et al 2001b). Until a greater understanding and appreciation of ponds is achieved this type of modelling will not be possible for ponds. New guidelines for sampling and a network of sites across the UK have been established to address some of these issues (Williams et al 2000), although it will be some time before long-term baseline data are available.

The management of existing ponds and creation of new sites to provide habitat for taxa of specific conservation interest, wildlife in general or for recreation and public appreciation may all be desirable, but should be undertaken with care (Williams et al, 2000). In the past, lack of information regarding ponds has lead to the development of some widely held misconceptions concerning the management of ponds for nature conservation. Some of the most damaging misconceptions include the belief that maintaining open water by the physical removal of aquatic vegetation, silt, and trees shading the water surface is vitally important for all ponds (Biggs et al 1994). Since almost all ponds are utilised by aquatic organisms irrespective of size, age, naturalness or degree of permanence, it is important that habitat diversity is maintained rather than creating a pond 'stereotype'. Dredging a temporary pond to create a more permanent water body will almost certainly eliminate aquatic flora or fauna adapted to ephemeral habitats (Biggs et al 2001). In most instances, the physical alteration of an existing pond is unnecessary and the most important factor is to ensure that water quality is maintained by the protection of the surrounding catchment. 
Ponds have considerable amenity value in the urban and rural environment. Increasingly, ponds are being created for specific anthropogenic purposes, for example, to provide flood water storage in urban areas and to provide settling and storage basins for fine sediments and pollutants. Public awareness of ponds has improved due to the increasing number that are located within nature reserves and Pond Warden Schemes established to develop and encourage local interest in pond preservation and conservation (Boothby et al 1995). The British Trust for Conservation Volunteers (BTCV) actively involves local communities in the management and conservation of ponds. The BTCV promotes 'Pond Weeks' to encourage the general public to become involved in the monitoring and management of ponds and to place them at the centre of the community (King 1999). These are all valuable exercises in raising public awareness and the understanding of pond habitats and the organisms they support.

Ornamental and garden ponds have been excluded from most historic studies due to difficulties in obtaining access, and their inclusion in future studies is essential. Garden ponds provide a haven for amphibians, plants and invertebrate fauna in the urban environment. However, many of these ponds contain high densities of ornamental fish (e.g., goldfish, Koi carp) that may feed on aquatic vegetation and invertebrate taxa, and thereby reduce the overall biodiversity of the pond. Due to the current popularity of ponds as garden features the number of non-native plant species introduced is likely to be substantial. The Lowland Pond Survey 1996 indicated that $14 \%$ of the ponds surveyed supported one or more exotic plant species and the figure for garden ponds is likely to be substantially higher (Williams et al 1998). In addition, it is possible that exotic 
invertebrate fauna will be introduced into ponds with plants, and may ultimately disperse into the wider environment.

Ponds remain an important landscape feature in the UK even though the traditional function of ponds in agriculture and industry may have changed. Management and conservation of individual ponds and pondscapes may be required to ensure the protection of habitat, the survival of individual species and overall pond biodiversity. It is also essential to maintain the diversity of pond types within the landscape. Further research is required to increase our understanding of pond habitats and ecology, and the importance of maintaining connectivity within pondscapes. However, greater public awareness and participation may ultimately be required to ensure the continued survival of ponds and pondscapes.

\section{Acknowledgements}

We gratefully acknowledge the helpful and constructive comments of colleagues following a lunchtime research seminar presentation given in the Department of Geography, Loughborough University. Thanks to Mark Szegner for the production of the figures for this paper and Professor G.N. Foster for permission to reproduce Figure 2. Thanks to Dr E. Brown for helpful comments on a draft of this manuscript and the constructive comments of two referees.

\section{References}

Allaby M 2000 Basics of Environmental Science: $2^{\text {nd }}$ Edition. Routledge, London.

Andrews J and Kinsman D 1990 Gravel Pit Restoration for Wildlife. Royal Society for the Protection of Birds, Sandy, Besdfordshire. 
Bailey-Watts T, Lyle A, Battarbee R, Harriman R, and Biggs J 2000 Lakes and Ponds in Acreman M ed The Hydrology of the UK: A Study of Change. Routledge, London 180-203.

Barnes R S K 1989 The coastal lagoons of Britain: An overview and conservation appraisal Biological Conservation 49 295-313.

Beebee T J C 1997 Changes in dewpond numbers and amphibian diversity over 20 years on chalk Downland in Sussex, England Biological Conservation 81 215-219.

Beresford J E and Wade P M 1982 Field ponds in North Leicestershire: their characteristics, aquatic flora and decline Transactions of the Leicester Literary and Philosophical Society 76 25-34.

Berglund B E 1996 Palaeoecological events during the last 15,000 years: regional syntheses of palaeoecologcal studies of lakes and mires in Europe. John Wiley and Sons, Chichester.

Biggs J, Corfield A, Walker D, Whitfield M and Williams P 1994 New approaches to the management of ponds British Wildlife 5 273-287.

Biggs J, Fox G, Nicolet P, Whitfield M and Williams P 2001 Dangers and opportunities in managing temporary ponds Freshwater Forum 17 71-80.

Bilton D T, Foggo A and Rundle SD 2001 Size, permanence and the proportion of predators in ponds Archiv für Hydrobiologie 151 451-458.

Birks H H, Battarbee R W and Birks H J B 2000 The development of the aquatic ecosystems at Kråkenes Lake, western Norway, during the late-glacial and early Holocene - a synthesis Journal of Paleolimnology 23 91-114.

Boecklen W J 1997 Nestedness, biogeographical theory, and the design of nature reserves Oecologia 112 123-142. 
Boothby J 1997 Ponds conservation: towards a delineation of pondscape Aquatic Conservation: Marine and Freshwater Ecosystems 7 127-132

Boothby J and Hull A P 1997 A census of ponds in Cheshire, North West England Aquatic Conservation: Marine and Freshwater Ecosystems 7 75-79.

Boothby J, Hull A P and Jeffreys D A 1995 Sustaining a threatened landscape: Farmland Ponds in Cheshire Journal of Environmental Planning and Management 38 $561-568$.

Bradley D C and Ormerod S J 2001 Community persistence among stream invertebrate tracks the North Atlantic Oscillation Journal of Animal Ecology 70 987-996.

Bratton J H and Fryer G 1990 The distribution and ecology of Chirocephalus diaphanus Prevost (Brachiopods, Anostraca) in Britain Journal of Natural History 24 955-964.

Buckley J 2001 The conservation and management of amphibians in UK temporary ponds, with particular reference to Natterjack toads Freshwater Forum 17 54-62.

Burger J 2000 Landscape, tourism and conservation The Science of the Total Environment 249 39-49.

Calow P and Petts G E 1994 The Rivers Handbook Volume 2: Hydrological and Ecological Principles Blackwell Scientific, Cambridge.

\section{Collinson N H, Biggs J, Corfield A, Hodson M J, Walker D, Whitfield M and}

Williams P 1995 Temporary and permanent ponds: an assessment of the effect of drying out on the conservation value of aquatic macroinvertbrates Biological Conservation 74 125-133.

Denton J S, Hitchings S P, Beebee T J C and Gent A 1997 A recovery program for the natterjack toad (Bufo calamita) in Britain Conservation Biology 11 1329-1338.

Drake M 2001 The importance of temporary water for Diptera (true-flies) Freshwater Forum 17 26-39 
Duigan C A and Jones A T 1997 Pond conservation symposium: introduction Aquatic Conservation Marine and Freshwater Ecosystems 7 87-89.

Everard M, Blackham B, Rouen, K, Watson W, Angell A and Hull A 1999 How do we raise the profile of ponds? Freshwater Forum 12 32-43.

Foster G N 1999 Biodiversity action plans for British water beetles Latissimus 11 1-13.

Foster G N 2000 The aquatic Coleoptera of British saltmarshes: extremes of generalism and specialism in Sherwood B R, Gardiner B G and Harris $\mathbf{T}$ eds British Saltmarshes Linnean Society, London 223-233.

Gardiner J L 1997 River landscapes and sustainable development: a framework for project appraisal and catchment management Landscape Research 22 95-114.

Gee J H R, Lee K M, Smith B D and Griffiths S W 1997 The conservation and amenity value of farm ponds in Wales in Boon P J and Howell D L eds Freshwater Quality: Defining the Indefinable? The Stationary Office, Edinburgh 428-434.

Giles C and Goodall I H 1992 Yorkshire Textile Mills 1770-1930 HMSO, London.

Godreau V, Bornette G, Frochot B, Amoros C, Castella E, Oertli B, Chambaud F, Oberti D and Craney E 1999 Biodiversity in the floodplain of Saône: a global approach Biodiversity and Conservation 8 839-864.

Greenwood M T and Wood P J 2003 Effects of seasonal variation in salinity on a population of Enochrus bicolor Fabricius 1792 (Coleoptera: Hydrophilidae) and implications for other beetles of conservation interest Aquatic Conservation: Marine and Freshwater Ecosystems 13 21-34.

Griffiths R A 1997 Temporary ponds as amphibian habitats Aquatic Conservation: Marine and Freshwater Ecosystems 7 119-126.

Hanski I 1999 Metapopulation Ecology Oxford University Press, Oxford. 
Heath D J and Whitehead A 1992 A survey of pond loss in Essex, south-east England Aquatic Conservation: Marine and Freshwater Ecosystems 2 267-273.

Jeffries M and Mills D 1990 Freshwater Ecology: Principles and Applications John Wiley and Sons, Chichester.

King M 1999 Ponds, puddles and people: community involvement in pond conservation a review of principles and practice in Boothby $\mathbf{J}$ ed Ponds and Pond Landscapes of Europe Pond Life Project, Liverpool 155-160.

Langton T 1985 The London pond survey Oryx 19 163-166.

Linton S and Goulder R 2000 Botanical conservation value related to origin and management of ponds Aquatic Conservation: Marine and Freshwater Ecosystems 10 $77-91$.

Lott D 2001 Ground beetles and rove beetles associated with temporary ponds in England Freshwater Forum 17 40-53.

Mackay J M 1997 Legislative and tenancy mechanisms for pond protection and management in Boothby $\mathbf{J}$ ed British Pond Landscape: Action for Protection and Enhancement Pond Life Project, Liverpool 121-128.

Mason C F, Heath D J and Gibbs D J 1991 Invertebrate assemblages of Essex salt marshes and their conservation importance Aquatic Conservation Marine and Freshwater Ecosystems 1 123-137.

Miles J, Cummins R P, French D D, Gardner S, Orr J L and Shewry M C 2001 Landscape sensitivity: an ecological view Catena 42 124-141.

Müller Z, Jakab T, Tóth A, Dévai G, Szállassy N, Kiss B and Horváth R 2003 Effects of sports fisherman activities on dragonfly assemblages on a Hungarian river floodplain Biodiversity and Conservation 12 167-179. 
Nicolet P 2001 Temporary ponds in the UK: a critical biodiversity resource for freshwater plants and animals Freshwater Forum 17 16-25.

Oldham R S and Humphries R N 2000 Evaluating the success of great crested newt (Triturus cristatus) translocation Hepterological Journal 10 183-190.

Pond Action 1993 A future for Britain's Ponds: An Agenda for Action. Pond Conservation Working Group, Oxford.

Rackham O 1986 The History of the Countryside: The Classic History of Britain's Landscape, Flora and Fauna Dent, London.

Rees S E 1997 The historical and cultural importance of ponds and small lakes in Wales, UK Aquatic Conservation: Marine and Freshwater Ecosystems 7 133-139.

Rouen K 2001 Use of the terms 'ponds' and 'pools' Freshwater Forum 174.

Sage B 1996 Coleoptera of Holkham national nature reserve, Norfolk Transactions of the Norfolk and Norwich Naturalists Society 30 523-551.

Savage A A 2000 Community structure during a 27-year study of the macroinvertebrate fauna of a chemically unstable lake Hydrobiologia 421 115-127.

Sherwood B R, Gardiner B G and Harris T 2000 British Saltmarshes Linnean Society, London.

Spiers D C, Gurney W S C, Hildrew A G and Winterbottom J H 2000 Long-term demographic balance in the Broadstone stream insect community Journal of Animal Ecology 69 45-58.

Stanton W I 1995 Ancient ponds and farm water supplies on Mendip Proceedings of the Bristol Naturalists’ Society 55 19-26.

Stubbs D 1999 Encouraging pond conservation on golf courses in Boothby $\mathbf{J}$ ed Ponds and Pond Landscapes of Europe Pond Life Project, Liverpool 213-218. 
Williams P, Biggs J, Barr C J, Cummins C P, Gillespie M K, Rich T C G, Baker A, Baker J, Beesley J, Corfield A, Dobson D, Culling A S, Fox G, Howard D C, Luursema K, Rich M, Samson D, Scott W A, White R and Whitfield M 1998 Lowland Pond Survey 1996. Department of Environment, Transport and the Regions, London.

Williams P, Biggs J, Corfield A, Fox G, Walker D and Whitfield M 1997 Designing new ponds for wildlife British Wildlife 8 137-150.

Williams P, Biggs J, Whitfield M, Thorne A, Bryant S, Fox G and Nicolet P 2000 The Pond Book: A guide to the management and creation of ponds The Pond Conservation Trust, Oxford.

Williams P, Biggs J, Fox G, Nicolet P and Whitfield M 2001 History, origins and importance of temporary ponds Freshwater Forum 17 7-15.

Wood P J and Barker S A 2000 Old industrial mill ponds: a negelcted ecological resource Applied Geography 20 65-81.

Wood P J, Greenwood M T, Barker S A and Gunn J 2001a The effects of amenity management for angling on the conservation value of aquatic invertebrate communities in old industrial ponds Biological Conservation 102 17-29.

Wood P J, Hannah D M, Agnew M D and Petts G E 2001b Scales of hydroecological variability within a groundwater-dominated stream Regulated Rivers: Research and Management 17 347-367.

Wright J F, Blackburn J H, Gunn R J M, Furse M T, Armitage P D, Winder J M and Symes K L 1996 Macroinvertebrate frequency data for the RIVPACS III sites in Great Britain and their use for conservation evaluation Aquatic Conservation: Marine and Freshwater Ecosystems 6 141-167. 


\section{List of Tables and Figures}

Table I. Comparison of macroinvertebrate biodiversity in ponds and rivers in the United Kingdom indicating species richness, nationally scarce and rare Red Data Book species.

Table II. Freshwater animals and plants given full protection under Schedules 5 and 8 of the Wildlife and Countryside Act 1981 (Adapted from Williams et al, 1998).

Table III. Aquatic Coleoptera of conservation interest recorded at the Flag Creek brackish water pond, Brightlingsea, Essex (Adapted from Greenwood and Wood 2003).

Table IV. Estimates of pond loss from different parts of the UK.

Figure 1. Density of ponds in England and Wales in the 1920s (adapted from Rackham, 1986)

Figure 2. Distribution map of Enochrus bicolor in the United Kingdom and Ireland. Courtesy of the Balfour-Browne Club. 
Table I. Comparison of macroinvertebrate biodiversity in ponds and rivers in the United Kingdom indicating species richness, nationally scarce and rare Red Data Book species.

\begin{tabular}{|c|c|c|c|c|c|c|c|}
\hline \multicolumn{2}{|c|}{ Invertebrate Group } & \multicolumn{2}{|c|}{$\begin{array}{l}\text { Species } \\
\text { Richness }\end{array}$} & \multicolumn{2}{|c|}{$\begin{array}{c}\text { Nationally Scarce } \\
\text { Species }\end{array}$} & \multicolumn{2}{|c|}{$\begin{array}{c}\text { Red Data Book } \\
\text { Species }\end{array}$} \\
\hline & Common Name & Ponds & Rivers & Ponds & Rivers & Ponds & Rivers \\
\hline Planariidae & Flatworms & 8 & 9 & 1 & 0 & 0 & 0 \\
\hline Mollusca & Snails \& orb mussels & 34 & 33 & 1 & 2 & 4 & 2 \\
\hline Hirudinea & Leeches & 10 & 14 & 1 & 0 & 0 & 0 \\
\hline Crustacea & Shrimps, slaters \& crayfish & 6 & 10 & 0 & 0 & 0 & 0 \\
\hline Ephemeroptera & Mayflies & 19 & 37 & 0 & 1 & 1 & 3 \\
\hline Plecoptera & Stoneflies & 7 & 27 & 0 & 1 & 0 & 0 \\
\hline Odonata & Dragonflies & 26 & 13 & 4 & 2 & 1 & 0 \\
\hline Hemiptera & Water Bugs & 45 & 27 & 2 & 0 & 1 & 0 \\
\hline Coleoptera & Water Beetles & 170 & 100 & 60 & 27 & 13 & 4 \\
\hline Megaloptera & Alderflies \& spongeflies & 2 & 3 & 0 & 1 & 0 & 0 \\
\hline Trichoptera & Caddis flies & 71 & 95 & 3 & 7 & 1 & 4 \\
\hline \multicolumn{2}{|c|}{ Total number of species } & 398 & 368 & 72 & 41 & 21 & 13 \\
\hline
\end{tabular}

Modified from Williams et al, (1998) and Bailey-Watts et al, (2000). Comparison is based on data from 156 sites in the National Pond Survey (Williams et al, 1998) and 614 sites from the RIVPACS programme (Wright et al, 1996). The comparison is based on all invertebrate groups sampled in both surveys for which reliable published national distribution and status data are available.

Note:- Numbers of taxa given by Wright et al, (1996) in Table 1 were modified to enable simple comparisons to be made see Williams et al, (1998) for details. 
Table II. Freshwater animals and plants given full protection under Schedules 5 and 8 of the Wildlife and Countryside Act 1981 (Adapted from Williams et al, 1998).

\begin{tabular}{|c|c|c|c|}
\hline Species & $\begin{array}{l}\text { Aquatic } \\
\text { Habitats }\end{array}$ & Species & $\begin{array}{l}\text { Aquatic } \\
\text { Habitats }\end{array}$ \\
\hline Mammals & & Invertebrates (Continued) & \\
\hline Lutra lutra (Otter) & $\mathrm{R}, \mathrm{L}, \mathbf{P}$ & Paracymus aeneus (a water beetle) & BP \\
\hline \multirow[t]{2}{*}{ Arvicola terrestris (Water Vole) } & $\mathbf{P}, \mathrm{R}$ & $\begin{array}{l}\text { Hydrochara caraboides (Lesser silver diving } \\
\text { beetle) }\end{array}$ & $\mathbf{P}$ \\
\hline & & Dolomedes platarius (Fen Raft Spider) & $\mathbf{P}$ \\
\hline \multicolumn{4}{|c|}{${ }^{2}$} \\
\hline Accipenser sturio (Sturgeon) & $\mathrm{R}$ & Plants & $\mathbf{P}$ \\
\hline Alosa alosa (Allis Shad) & $\mathrm{R}$ & $\begin{array}{l}\text { Ranunculus ophioglossifolius (Adder's- } \\
\text { tongue Spearwort) }\end{array}$ & $\mathbf{P}$ \\
\hline Coregonus albula (Vendace) & $\mathrm{L}$ & Cyperus fuscus (Brown Galingale) & WG \\
\hline Coregonus laveratus (Powan) & $\mathrm{L}$ & Apium repens (Creeping Marshwort) & $\mathbf{P}$ \\
\hline \multirow{2}{*}{ Lota lota (Burbot) } & $\mathrm{R}$ & Liparius loeselii (Fen Orchid) & $\mathbf{P}$ \\
\hline & & Luronium natans (Floating water-plantain) & $\mathbf{P}$ \\
\hline Amphibians ${ }^{1}$ & & Lythrum hyssopifolia (Grass-poly) & $\mathrm{L}$ \\
\hline Bufo calamita (Natterjack toad) & $\mathbf{P}$ & Najas flexilis (Slender Naiad) & $\mathrm{L}$ \\
\hline Triturus cristatus (Great crested newt) & $\mathbf{P}$ & Najas marina (Holly-leaved Naiad) & $\mathbf{P}$ \\
\hline \multirow{2}{*}{ Rana lessonae (Pool frog) } & $\mathbf{P}$ & Mentha pulegium (Pennyroyal) & $\mathbf{P}$ \\
\hline & & Crassula aquatica (Pigmyweed) & $\mathbf{P}$ \\
\hline Invertebrates & & $\begin{array}{l}\text { Alisma graminuem (Ribbon-leaved Water- } \\
\text { plantain) }\end{array}$ & $\mathbf{P}$ \\
\hline Hirudo medicinalis (Medicinal leech) & $\mathbf{P}$ & Damasonium alisma (Starfruit) & $\mathbf{P}$ \\
\hline Myax glutinosa (Glutinous snail) & $\mathbf{P}$ & Corigiola littoralis (Strapwort) & $\mathbf{P}$ \\
\hline Margaritifera margaritifera (a pearl mussel) & $\mathrm{R}$ & Limosella ausralis (Welsh Mudwort) & $\mathbf{P}$ \\
\hline Triops cancriformis (a tadpole shrimp) & $\mathbf{P}$ & $\begin{array}{l}\text { Cryphaea lamyana (Multi-fruited River- } \\
\text { moss) }\end{array}$ & $\mathrm{R}$ \\
\hline Chirocepalus diaphanus (a fairy shrimp) & $\mathbf{P}$ & Chara canescens (Bearded Stonewort) & $\mathbf{P}$ \\
\hline $\begin{array}{l}\text { Austropotamobius pallipes (Atlantic stream } \\
\text { crayfish) }\end{array}$ & $\mathrm{R}$ & Colemma dichotomum (River Jelly Lichen) & $\mathrm{R}$ \\
\hline Grapoderus zonatus (spangled water beetle) & $\mathbf{P}$ & & \\
\hline
\end{tabular}

Key:- R = River; L = Lake; P = Pond; BP = Brackish Pond and WG = Wet Grassland.

Note:- ${ }^{1}$ The Common Toad (Bufo bufo), Smooth Newt (Triturus vulgaris) and Palmate Newt (Triturus helvetica) are not given complete protection and have been excluded from the table. 
Table III. Aquatic Coleoptera of conservation interest recorded at the Flag Creek brackish water pond, Brightlingsea, Essex (Adapted from Greenwood and Wood 2003)

Taxa

Conservation Status ${ }^{\text {a }}$

\begin{tabular}{cc}
$\begin{array}{c}\text { Red Data Book } \\
(\mathrm{GB})\end{array}$ & IUCN proposed status \\
\hline
\end{tabular}

Enochrus bicolor Fabricius

$\mathrm{Nb} \quad$ LRnsB

Ochthebius marinus (Payk.)

$\mathrm{Nb} \quad$ LRnsB

Ochthebius viridis Peyrhiff

$\mathrm{Nb} \quad$ LRnsB

Ochthebius punctatus Steph.

$\mathrm{Nb} \quad$ LRnsB

Hygrotus parallelogrammus (Ahrens)

$\mathrm{Nb} \quad$ LRnsB

Berosus affinis Brulle

$\mathrm{Nb} \quad$ LRnsB

Agabus conspersus (Marsham)

$\mathrm{Nb} \quad$ LRnsB

Rhantus frontalis (Marsham)

Rhantus suturalis (MacLeay)

$\mathrm{Nb}$

Paracymus aeneus Fabricus

$\mathrm{Nb}$

LRnsB

RDB1

EN

Haliplus apicalis Thomson

$\mathrm{Nb}$

LRnsB

Note:- ${ }^{\mathrm{a}}$ Conservation status based on Foster (2000); IUCN $=$ The World Conservation Union; $\mathrm{Nb}=$ Nationally Notable List B; RDB1 = Red Data Book category 1; LRnsB = IUCN Red List category - Lower Risk, nationally scarce, list $\mathrm{B}$ and $\mathrm{EN}=\mathrm{IUCN}$ Red List category - endangered. 
Table IV. Estimates of pond loss from different parts of the UK.

\begin{tabular}{|c|c|c|c|c|c|c|}
\hline Area & Period & $\begin{array}{l}\text { Loss } \\
(\%)\end{array}$ & $\begin{array}{l}\text { Annual } \\
\text { Loss }(\%)\end{array}$ & $\begin{array}{l}\text { Change in number of Ponds } \\
\text { (n) }\end{array}$ & Landuse & Source \\
\hline Huddersfield & $1985-1997$ & 31 & 2.60 & $60-42$ & Urban / Industrial & Wood et al 2001a \\
\hline North Leicestershire & $1934-1979$ & 60 & 1.33 & $958-370$ & Mostly pasture & Beresford and Wade 1982 \\
\hline Bedfordshire & $1910-1981$ & 82 & 1.15 & Not quoted & Intensive arable & Beresford and Wade 1982 \\
\hline Sussex & $1977-1996$ & 21 & 1.10 & $33-26$ & Pasture (Dewponds) & Beebee 1997 \\
\hline London region & $1870-1984$ & Up to 90 & 0.79 & up to $16000-1600$ & Mixed & Langton 1984 \\
\hline Huntingdonshire (Cambs.) & $1890-1980$ & 56 & 0.68 & Not quoted & Mixed & Beresford and Wade 1982 \\
\hline Cheshire & $1870-1993$ & 61 & 0.50 & $41564-16728$ & Rural and urban & Boothby and Hull 1997 \\
\hline Essex (selected areas) & $1870-1989$ & $55-69$ & $0.46-0.58$ & 1366 to between 616 and 423 & Mixed & Heath and Whitehead 1992 \\
\hline Cambridgeshire & $1840 / 90-1990$ & 68 & $0.45-0.68$ & Not quoted & Intensive arable & Jeffries and Mills 1990 \\
\hline Leicestershire & $1840 / 90-1990$ & 60 & $0.40-0.60$ & Not quoted & Intensive arable & Jeffries and Mills 1990 \\
\hline Durham & $1840 / 90-1990$ & 41 & $0.27-0.41$ & Not quoted & Arable and pasture & Jeffries and Mills 1990 \\
\hline Clwyd & $1840 / 90-1990$ & 32 & $0.21-0.32$ & Not quoted & Arable and pasture & Jeffries and Mills 1990 \\
\hline Midlothian & $1840 / 90-1990$ & 23 & $0.15-0.23$ & Not quoted & Arable and pasture & Jeffries and Mills 1990 \\
\hline Edinburgh & $1840 / 90-1990$ & 6 & $0.04-0.06$ & Not quoted & Urban & Jeffries and Mills 1990 \\
\hline England and Wales & $1880-1920$ & 57.5 & 1.41 & $800000-340000$ & Mixed & Rackham 1986 \\
\hline Britain & $1990-1996$ & 7.4 & 1.23 & $230600-228900$ & Mixed - lowland ponds & Williams et al 1998 \\
\hline Great Britain & $1900-1990$ & 75 & 0.78 & $1189200-297300$ & Mixed & Bailey-Watts et al 2000 \\
\hline
\end{tabular}


Ponds per $\mathrm{km}^{2}$

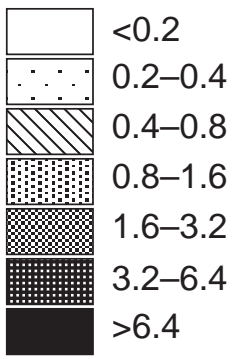

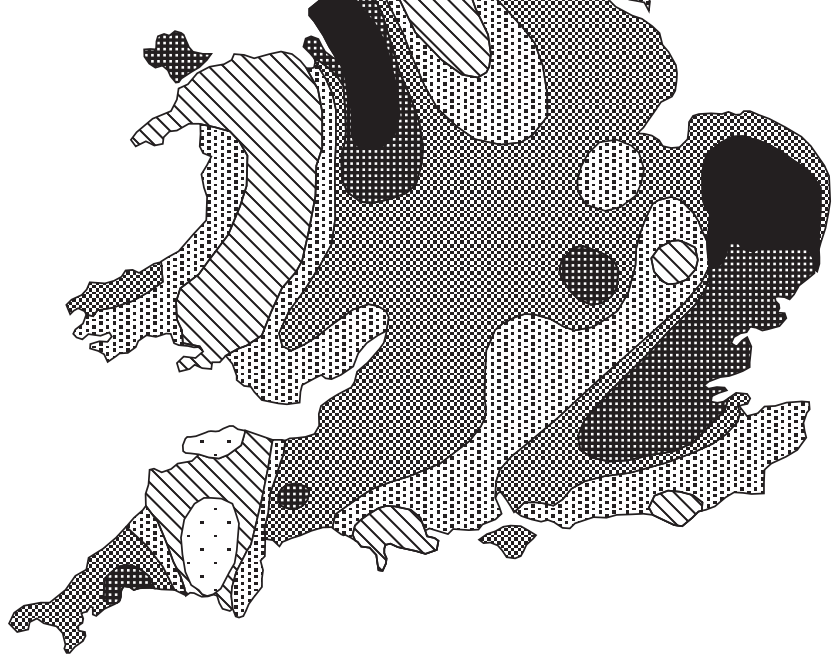



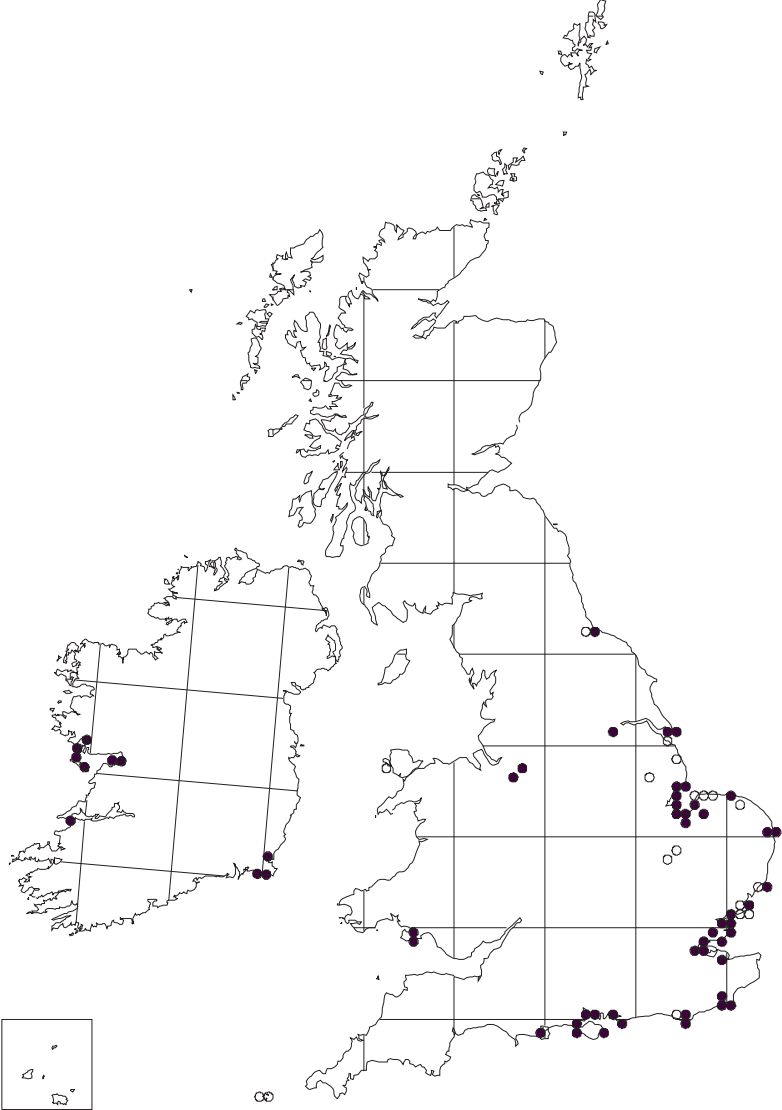